\title{
"Nicarágua na encruzilhada": Cortázar, Vargas Llosa e a experiência sandinista
}

"Nicaragua on the crossroad": Cortázar, Vargas Llosa and the sandinista experience Adriane Vidal Costa

Vinte anos depois da vitória dos revolucionários em Cuba ocorreu a vitória dos sandinistas na Nicarágua. Os acontecimentos em Cuba ao longo das décadas de 1960 e 70 direcionaram, em grande medida, o debate político-intelectual sobre a experiência sandinista na Nicarágua. As comparações foram inevitáveis, já que as duas experiências caracterizaram-se como revoluções de libertação nacional com um mesmo fim - derrubar uma ditadura, romper com o imperialismo norte-americano e erigir uma sociedade socialista - e um mesmo meio - a luta armada. Julio Cortázar participou diretamente dessa experiência e depositou toda a esperança na construção do socialismo no país. Mario Vargas Llosa, nesse momento já "desvinculado" das esquerdas latino-americanas, ado-

Adriane Vidal Costa é professora de história da América na rede privada de ensino superior em Belo Horizonte, Brasil (adrianevidal@yahoo.com.br).

Artigo recebido em 30 de junho de 2009 e aprovado para publicação em $1^{\circ}$ de outubro de 2009.

Est. Hist., Rio de Faneiro, vol. 22, n. 44, p. 479-503, julho-dezembro de 2009. 
tou uma postura mais crítica com relação à experiência sandinista, usando Cuba como contraponto.

Apesar das comparações possíveis, a experiência revolucionária nicaraguense diferiu da cubana em muitos aspectos. Para Emir Sader (1992: 55), a experiência sandinista, do ponto de vista do processo que levou a Frente Sandinista de Libertação Nacional (FSLN) ao poder, aproxima-se da Revolução Cubana. Porém, no decorrer do processo, diferentemente de Cuba e à semelhança do Chile de Salvador Allende, os sandinistas propuseram um sistema político multipartidário e uma economia mista. Fidel Castro deu amplo apoio militar e logístico aos sandinistas durante a luta contra Somoza; e quando eles tomaram o poder enviou assessores militares, professores e médicos, com o intuito de ajudar a consolidar o novo regime de esquerda.

Em 1961, três líderes estudantis, Carlos Fonseca, Tomás Borge e Silvia Mayorga, inspirados na Revolução Cubana, fundaram uma organização revolucionária chamada Movimento Nova Nicarágua $(\mathrm{MNN})$, com o intuito de derrubar a ditadura Somoza e romper com o imperialismo norte-americano. ${ }^{1}$ Pouco depois, o MNN passou a se chamar Frente de Libertação Nacional (FLN), inspirado no grupo armado que havia derrubado o colonialismo francês na Argélia. O acréscimo sandinista ao nome do movimento foi sugestão de Carlos Fonseca, que, vivendo em Cuba no início da década de 1960, "redescobriu" Augusto César Sandino, um líder guerrilheiro dos anos 1920 e 30, que lutou contra a ocupação militar norte-americana na Nicarágua, que se concretizava através da presença dos marines (fuzileiros navais) no país. ${ }^{2} \mathrm{Em}$ Cuba, além de ficar sabendo que Fidel Castro e Che Guevara estudaram as táticas de guerra de guerrilhas de Sandino, Carlos Fonseca teve acesso ao livro do socialista argentino Gregório Selser, Sandino: general de hombres livres, publicado originalmente em 1955. Desde então, ele começou a buscar inspiração e um novo modelo estratégico em Sandino.

A FSLN travou uma luta de 18 anos contra a ditadura Somoza e sua Guarda Nacional. Durante esse período, as forças sandinistas solidificaram o apoio rural e urbano; realizaram assaltos a bancos e sequestros; centraram suas atividades no trabalho de conscientização das "massas" e na guerrilha; estudaram sistematicamente outras experiências revolucionárias, como a cubana, a argelina, a vietnamita e a chinesa; aprofundaram seu conhecimento sobre o país; definiram com maior precisão as forças sociais que deveriam estar envolvidas com o processo revolucionário: massas urbanas, operários e camponeses. Em fins da década de 1970, a FSLN estava em seu auge. Em 1978, tomou o Palácio Nacional, ação que repercutiu internacionalmente e desmoralizou a Guarda Nacional. No começo do ano seguinte, o movimento iniciou diversas ações no Oeste e no Norte do país, e, depois de seguidas vitórias, veio a ofensiva final e Anastacio Somoza Debayle fugiu do país. Em 19 de julho de 1979, as forças da FSLN ocu- 
param Manágua, encerrando a longa ditadura somozista. Era o início da difícil tarefa de reorganizar o país com a Junta de Reconstrução Nacional que incorporava todas as oposições e organizações populares num amplo projeto antioligárquico e anti-imperialista. ${ }^{3}$ A partir de então, revelava-se com maior intensidade a postura ideológica da FSLN, pautada na combinação de elementos de diferentes matrizes: do marxismo à Teologia da Libertação, da social-democracia à tradição anti-imperialista latino-americana (Rodrigues, 1996: 367).

Em maio de 1980, foi criado o Conselho de Estado, integrado por representantes dos variados grupos sociais e das organizações ligadas aos sandinistas. Eleições foram convocadas para 1984, quando a FSLN obteve $67,2 \%$ dos votos para a Presidência, elegendo o sandinista Daniel Ortega. A partir de então, a tarefa era consolidar a revolução, tarefa dificultada pelas contradições internas do próprio governo e pelas ações dos contrarrevolucionários e dos EUA, sobretudo depois que Ronald Reagan, sucedendo Jimmy Carter, assumiu a presidência do país, imprimindo um tom mais agressivo à política externa norte-americana. $\mathrm{O}$ epílogo da experiência sandinista ocorreu em 1990, quando a FSLN perdeu as eleições para Violeta Chamorro, candidata dos partidos de oposição reunidos na coalizão União Nacional Opositora (UNO), apoiada pelo governo dos Estados Unidos.

\section{Julio Cortázar: "Nicarágua tão violentamente doce"}

O triunfo revolucionário dos sandinistas alimentou um novo otimismo em Cortázar, ${ }^{4}$ depois de certa desilusão com os caminhos da Revolução Cubana. ${ }^{5}$ Ele acreditava que o modelo revolucionário na Nicarágua poderia ser o modelo que tanto idealizou, por isso, enquanto viveu, foi um dos intelectuais mais militantes e atuantes no processo revolucionário nicaraguense. Ali, ajudou a fundar o primeiro Museu de Arte Contemporânea do país; opinou sobre o amplo processo de alfabetização; participou de várias reuniões e mesas-redondas e ajudou a organizar a Primera Reunión del Comité Permanente de Intelectuales por la Soberania de los Pueblos de Nuestra América, em 1982. Por sua solidariedade com a Revolução Sandinista, em 1983, Sérgio Ramírez o condecorou, em nome da Junta de Governo, com a Orden de la Independencia Cultural Rubén Darío. Cortázar (2000: 1763) registrou em vários momentos o seu comprometimento com a causa sandinista e sua admiração pelos "nicas", "gente admirável frente às dificuldades e aos perigos", que estavam constantemente à espera de uma invasão de contrarrevolucionários manipulados pelos EUA. Porém, isso não impedia os "nicas" de seguir adiante "com seu trabalho e com sua alegria de viver". Por essas razões, Cortázar assinalou que iria quantas vezes fosse preciso à Nicarágua 
para participar de diálogos e reuniões, e ajudar no que fosse possível no plano da cultura.

Cortázar escreveu vários artigos militantes sobre a Nicarágua para mostrar à América Latina e ao mundo uma imagem do país diferente daquela difundida pelas agências informativas dos Estados Unidos e da Europa. O livro Nicaragua tan violentamente dulce, editado em Manágua, em 1983, reúne grande parte desses artigos. Entre eles, figura seu relato Apocalipsis de Solentiname, anterior ao triunfo revolucionário, e diversos textos escritos para apoiar o governo e condenar a agressão norte-americana. No conto Apocalipsis de Solentiname, o narrador-personagem, no caso o próprio Cortázar, relata sua viagem à Nicarágua, mais especificamente à ilha de Solentiname, onde o poeta e sacerdote nicaraguense Ernesto Cardenal ${ }^{6}$ havia desenvolvido um trabalho de conscientização dos camponeses da região, colocando em prática as ideias revolucionárias da Teologia da Libertação (Diogo, 2005: 68). Em Solentiname, o narrador se encantou com os quadros pintados pelos camponeses, que retratavam cenas bucólicas do cotidiano. Fascinado pelas pinturas, o narrador decidiu fotografá-las uma a uma de forma que elas ocupassem inteiramente o visor. Apesar da aparente tranquilidade na comunidade, o narrador concluiu que o medo da ameaça de serem atacados em pleno dia ou noite rondava aquele lugar, e não apenas a ilha, ou a Nicarágua, "mas quase toda a América Latina", que vivia rodeada de medo e de morte, como Argentina, Bolívia, Brasil, Chile, Colômbia, El Salvador, Guatemala, Paraguai e República Dominicana (Cortázar, 1987: 12).

De volta para sua casa, em Paris, o narrador do conto mandou revelar as fotos e as transformou em slides. Ao projetá-las, percebeu, então, que as imagens bucólicas das pinturas que fotografou em Solentiname desapareceram e deram lugar, inexplicavelmente, a cenas de violência, de repressão, de sequestro e de tortura na América Latina. Uma dessas cenas era o fuzilamento do poeta salvadorenho Roque Dalton, que ocorreu em 1975. Ao inserir no conto as mutações das fotografias, Cortázar introduziu o elemento fantástico na narrativa, diluindo a fronteira entre o real e a ficção. A mutação das fotografias é um elemento fantástico, mas o que ele definitivamente vê nessas imagens - cenas de violência e repressão na América Latina - são temas demasiadamente conhecidos para serem tomados como ficção. As referências a lugares, a personagens (como Ernesto Cardenal) são identificáveis com a história latino-americana. Além disso, Cortázar de fato esteve clandestinamente na ilha de Solentiname em 1976, onde se encontrou com os sandinistas, o que o levou a apoiar definitivamente a causa e o inspirou a escrever o conto. Em um artigo, Cortázar (1978: 49) confessou ter escrito Apocalipsis de Solentiname para mostrar que a literatura era uma das maneiras de atacar "o opróbrio e a opressão", mas sem cair no conteudismo. Assinalou que, apesar de ter mostrado 
no conto a ameaça e o perigo que rondava Solentiname, o relato não guardava nenhuma imagem premonitória do que havia acontecido depois, isto é, a real invasão e destruição da comunidade pela Guarda Nacional em 1977.

Após o triunfo revolucionário, uma das principais ações de Cortázar foi tornar a experiência sandinista conhecida no mundo inteiro e fomentar a solidariedade internacional em torno da "nova Nicarágua". Ele acreditava que a cultura deveria ser a arma principal na defesa do projeto sandinista no cenário internacional. Quatro meses depois da vitória, estava lá Cortazar comprovando a "reconstrução de um país devastado pela rapina, pelo terror, pelo monstruoso furor da mal chamada Guarda Nacional nas últimas etapas da luta”. Essa experiência foi relatada no artigo "Nicarágua, a nova". O primeiro contato de Cortázar com as ações revolucionárias ocorreu quando participou de uma mesa-redonda na Universidade Centro-Americana (UCA), com a assistência de escritores e estudantes, para debaterem os rumos da campanha de alfabetização no país. Nesse primeiro contato, Cortázar percebeu que todos se engajavam nessa campanha discutindo planos, contingentes e distribuindo esforços. A primeira ajuda internacional que chegou à Manágua, segundo Cortázar, foi de Cuba, que contribuiu com um contingente de cem professores, com "larga experiência em alfabetização", para orientar estudantes universitários e colegiais que seriam os alfabetizadores da campanha. No artigo "O povo da Nicarágua, professor de si mesmo", Cortázar demonstrou que a educação e a campanha de alfabetização seriam os grandes aliados na tarefa de tirar homens e crianças da ignorância e dotá-los da capacidade de compreender o que estavam fazendo, por que era preciso fazê-lo e como deveriam fazê-lo. O grande desafio para a Junta de Governo, a seu ver, era a necessidade de construir mais escolas, refeitórios, ambulatórios e adquirir mais livros e vacinas (Cortázar, 1987: 18-33).

Para Cortázar, o confronto de vários anos entre a FSLN e os somozistas havia deixado um saldo mais que negativo no campo econômico e social. Na sua opinião, sem a ajuda externa seria muito difícil para o governo solucionar os problemas mais graves do país. Em todos os artigos sobre a Nicarágua, Cortázar insistia demasiadamente na solidariedade internacional com o envio imediato de alimentos, equipamentos, remédios, livros etc. Naquele momento, ajudar a Nicarágua significava, segundo ele, ajudar a causa da liberdade e da justiça na América Latina. No final do artigo, Cortázar se revelou otimista, incisivo e fez um apelo:

(...) ao terminar estas impressões tão cheias de luz e de esperança; talvez entre meus leitores internacionais exista algum ministro da economia, da agricultura ou da saúde, ou o presidente de alguma fundação ou de um consórcio bancário capazes de compreender esta dura realidade e de organizar planos de ação. 
A identificação de Cortázar com os sandinistas era tão forte que, nos artigos sobre a Nicarágua, ele assumia a posição de porta-voz da FSLN.

Em Cuba, após o triunfo da revolução, Cortázar (1987: 28-33) viu uma mobilização dramática e emocionante em busca de uma "autêntica tomada de consciência" destinada a arrancar o país do atraso e da ignorância. Após conhecer a realidade da nova Nicarágua, a comparação com Cuba, a precursora, foi inevitável:

Minha memória volta quase vinte anos e me vejo em minhas primeiras viagens a Cuba (...). Ouço Fidel falando às crianças como agora acabo de ouvir Ernesto Cardenal, o ministro da saúde, o comandante Borge, todos os que olham para frente e sabem que sempre, em algum lugar, há uma criança que espera e que confia.

Para Cortázar, a "Nicarágua nova" estava caminhando nessa mesma direção, com vistas inclusive a superar o modelo cubano. Tanto Cuba quanto a Nicarágua estavam abrindo o caminho que um dia deveria "seguir muitos outros em um continente onde o analfabetismo não era apenas um obstáculo ao progresso e ao desenvolvimento, mas um fator negativo na busca de "raízes autênticas e identidade profunda".

No artigo "Esboços da Nicarágua", Cortázar (1987: 41-51) mostrou como era o país antes de 1979 e como estava depois, com o intuito de apresentar a realidade àqueles que a conheciam apenas por meio da imprensa. Dessa forma, parte do artigo é um esboço relativamente esquemático de um antes e um depois: nos bairros onde havia ruas que pareciam lodaçais, agora estas eram asfaltadas; onde antes havia pântanos com porcos fuçando o lixo, agora passavam ônibus cheios de estudantes e trabalhadores; as casas, antes sujas e abandonadas, foram pintadas e limpas; os mercados de rua, antes abandonados, estavam sendo trocados por centros onde vendedores e clientes se encontravam em ambiente limpo e espaçoso. Enfim, ao ler seu artigo, o leitor estaria informado de que na Nicarágua os resultados eram sempre positivos e, como ele mesmo afirmou, de uma "evidência deslumbrante".

Ainda no artigo "Esboços da Nicarágua", Cortázar (1987: 41-44) apresentou ao leitor uma realidade marcada pela oposição ao governo sandinista, constituída pelos contrarrevolucionários e pelos Estados Unidos que, juntos, pretendiam devolver a Nicarágua à "sua condição anterior". ${ }^{7}$ A oposição, segundo ele, agia de duas formas: de um lado, desfraldava "os princípios abstratos de um liberalismo democrático que não era nem uma coisa nem outra", porque visava "apenas recuperar os privilégios dos latifundiários ou das grandes empresas comerciais e industriais"; de 
outro, organizava na fronteira com Honduras as milícias de "ex-soldados de Somoza, ávidos de reconquistar a sangue e fogo a terra perdida e vingar-se dos que os expulsaram”. Isso tinha, a seu juízo, consequências muito sérias, como a ameaça permanente de uma invasão, que gerava, ao mesmo tempo, medo permanente na população e impedia o direito à liberdade e à paz. Além disso, obrigava o governo a desviar recursos cada vez maiores para reforçar a defesa. ${ }^{8}$

Nos artigos "A Nicarágua vista de dentro" (I, II, III e IV), Cortázar (1987: 55-61) mais uma vez denunciou as agressões norte-americanas para desestabilizar o governo. Segundo ele, os Estados Unidos adotaram, assim como fizeram em Cuba, a política do bloqueio econômico e do congelamento de créditos, "buscando matar pela fome os que haviam se atrevido a despedaçar seu famoso quintal centro-americano". Além disso, Cortázar condenou as agências de notícias e os "colunistas liberais" de perpetrarem um jogo sujo para denegrir a imagem do regime, como fizeram com o regime cubano. As agências de notícias sempre mostravam uma Nicarágua, assim como Cuba, dependente da URSS, esquecendo que a presença soviética no país teria sido "o resultado direto da torpeza dos EUA" ao colocar Cuba diante da opção de aceitar uma ajuda essencial, a do petróleo da URSS, ou "arruinar-se em quinze dias como um barquinho de papel." Entretanto, afirmar que existia uma "ingerência soviética" na Nicarágua era, para Cortázar, uma hipocrisia. De fato não havia "ingerência soviética" na Nicarágua, mas os soviéticos enviaram conselheiros militares e armas para auxiliar o governo sandinista. ${ }^{9}$

O comprometimento de Cortázar com a causa sandinista era tão grande que, em fevereiro de 1983, acompanhado por 20 norte-americanos pacifistas e pela poetisa Claribel Alegría, participou de uma vigília pela paz em Bismuna, na fronteira com Honduras, onde ocorriam vários confrontos armados entre sandinistas e contrarrevolucionários. Ao descrever essa cena no artigo "Vigília em Bismuna", Cortázar (1987: 93-94), num arroubo de otimismo, afirmou: "uma vez mais o pequeno Davi se erguia diante do monumental Golias". Em uma carta endereçada a Julio Silva, ${ }^{10}$ antes da viagem para Bismuna, Cortázar confidenciou que iria para a zona de fronteira hondurenha para ter uma visão mais precisa $\mathrm{e}$ direta da situação, pois os conflitos naquela região seriam o tema de um artigo que escreveria para a agência de notícias espanhola EFE. Cortázar pediu a Julio Silva que guardasse total segredo sobre o conteúdo da correspondência e confessou que sabia dos perigos da região e estava temeroso do que podia lhe acontecer, pois mesmo não estando diretamente na linha de fogo, ele poderia ser vítima de uma emboscada. Caso lhe acontecesse o pior, era para Julio Silva entregar a carta para Claribel Alegría em Manágua, que, por sua vez, deveria entregá-la aos dirigentes sandinistas para que cumprissem seu desejo de ser enterrado na França. Como sabemos, Cortázar saiu ileso da aventura em Bismuna. 
Em setembro de 1982, Cortázar participou de um seminário sobre política cultural e libertação democrática na América Latina na Universidad Internacional Menéndez Pelayo na Espanha, no qual apresentou o texto "O escritor e sua atividade na América Latina", que, posteriormente, passou a figurar em $\mathrm{Ni}$ caragua tan violentamente dulce. Nesse texto, Cortázar, influenciado pelo seu compromisso com a experiência sandinista, se posicionou sobre o papel do intelectual. Como esse era um tema/problema que ele e muitos outros já vinham enfrentando há anos, era desnecessário reiterar noções que se tornaram muito claras para ele, como, por exemplo, a de levar "aos nossos povos" a consciência da liberdade e da autodeterminação. As velhas polêmicas sobre o compromisso do escritor, segundo ele, naquele momento, já estariam superadas por uma problemática concreta. Era então necessário superar a etapa das análises teóricas, que já estavam suficientemente esgotadas, e abrir caminho para ações concretas e intervenções diretas.

O compromisso do escritor deveria então ser o de incrementar sua participação no terreno geopolítico por meio do seu trabalho intelectual e de inventar novas formas de contato que diminuíssem cada vez mais a enorme distância que separava o escritor daqueles que ainda não podiam ser seus leitores. Os intelectuais nicaraguenses, na concepção de Cortázar (1987: 100), estavam no caminho certo da ação prática, pois articulavam sua obra vocacional com as variadas atividades que exerciam publicamente, como as de dirigentes revolucionários, administradores e interlocutores em mesas-redondas, reuniões e manifestações populares. Muitos poderiam questionar afirmando que isso seria factível apenas em situações de processos revolucionários, mas para Cortázar o exemplo dos intelectuais nicaraguenses servia de contraste para os intelectuais de outros países que "viviam na inércia" ou apegados "a etiquetas que os distinguiam do povo". Cortázar, de certo modo, estava defendendo a concepção de "intelectual orgânico"11 para o exercício da ação política. Prática intelectual que, indiretamente, havia criticado em Cuba, sobretudo após o "Caso Padilla".

A principal tarefa do escritor comprometido com os projetos das esquerdas seria aproximar seu trabalho intelectual do principal destinatário: o "povo". Para Cortázar (1987: 101), os escritores, incluindo ele, já haviam tido tempo suficiente para "imaginar e calcular o arco das pontes cada vez mais imprescindíveis entre o produto intelectual e seus destinatários". Assim sendo, o momento era de construir "essas pontes na realidade e pôr-se a andar nesse espaço a fim de que ele" se convertesse "em senda" e "comunicação tangível”, para o escritor, e "em vivência da literatura", para o "povo". Cortázar estava defendendo, de certa forma, que o escritor colocasse a criação literária a serviço de uma causa, "adequando-a" à realidade do seu principal destinatário, o "povo". Em 1963, quando publicou na revista Casa de las Américas o artigo Alguns aspectos del conto, ${ }^{12}$ tendo 
como tema a posição do escritor na Revolução, Cortázar foi mais reflexivo ao afirmar que era imprescindível evitar cair no doutrinamento ideológico e na literatura pedagógica. Além de ter advertido sobre os perigos de se fazer uma literatura "acessível a todo mundo" e "assimilável sem esforço". O compromisso com a causa sandinista tornou mais imperiosa a sua convicção sobre o papel do intelectual. O escritor, sem abandonar o trabalho de criação, deveria participar com ações práticas e precisas na luta para manter e criar condições efetivas para a revolução.

Para o escritor argentino, as "pontes" deveriam ser os contos, os poemas, os romances, as pinturas, a música, o teatro, as editoras etc. Segundo Cortázar (1987: 103-105), seria necessário imprimir algo de novo nessas pontes: a noção de que elas poderiam chegar à outra margem, onde nunca haviam chegado antes, onde havia "imensidões de povos" rodeados por um "silêncio de ignorância, de opressão, de falta de comunicação, de estrangeirismo". Caberia aos intelectuais estimular e facilitar os acessos imediatos do povo à cultura. Era chegada a hora da ação. Para Cortázar, na Nicarágua, a cultura estava rompendo com "todas as etiquetas" e as novas pontes estavam sendo construídas. Ao decidir eliminar o analfabetismo, o governo sandinista estava dando "o primeiro passo" para estimular e facilitar os acessos do povo à cultura. Porém, era necessário superar a "velha noção de cultura" como um "bem imóvel" e "fazer o impossível" para convertê-la "em um bem móvel, em um elemento da vida coletiva", como se fazia com os bens de consumo.

Em 1983, como já mostramos, Cortázar recebeu da Junta de Governo a Orden de la Independencia Cultural Rubén Darío. No ato da condecoração, discursou em agradecimento e fez um panorama sobre o que viu e sentiu no seu contato com a Nicarágua sandinista. Elegeu, claro, um fio condutor: a cultura. Um tema, segundo ele, inesgotável por definição, por seu caráter de difícil exatidão. Ainda assim, arriscou definir cultura como um processo cíclico e ininterrupto, como "uma dialética" que incidia "na história" e a refletia", como um "camaleão mental, sentimental e estético" que variava "suas cores conforme as sociedades" em que se manifestava (Cortázar, 1987: 117-118). Dessa forma, Cortázar achou mais útil optar por uma abordagem não abstrata de cultura, mas abordá-la dentro de um contexto dado para compreender suas especificidades e suas modalidades.

$\mathrm{Na}$ Nicarágua, a palavra cultura fazia parte de um programa extremamente variado, conduzido pelo Ministério da Cultura. Diferentemente do Ocidente europeu, onde, segundo Cortázar (1987: 120), cultura era privilégio de uma elite e apenas um dos diversos componentes da estrutura social, na Nicarágua a cultura estava presente em cada um dos avanços, das iniciativas e das realizações populares, deixando assim de ser privilégio de poucos para "explodir em 
milhares de pedaços, que se recompõem em uma síntese cada vez mais visível e que comporta igualmente milhares de vontades, de sentimentos, de opções e de atos". A seu ver, na Nicarágua, a cultura era um elemento sempre presente no espaço da política. Havia um grande interesse "das massas populares" pela coisa pública, pelos problemas comuns. Interesse que era demonstrado com clareza pelos atos e eventos mais variados de mobilização cultural e política. Neste sentido, para Cortázar, cultura era revolução e revolução era cultura, sem "compartimentações seletivas ou genéricas". A seu ver os dois principais aspectos positivos da Revolução Sandinista foram a "popularização" da cultura e as conquistas no campo social.

Nos artigos de Nicaragua tan violentamente dulce, escritos ao longo de quase sete anos, Cortázar expressou empatia com o povo nicaraguense, entusiasmo pelo destino da revolução e uma ira quase incontrolável pelos contrarrevolucionários e pelos Estados Unidos. Em fevereiro de 1984, Cortázar concedeu sua última entrevista, para Alberto Perrone, publicada na revista argentina 7 Días, na qual expressou novamente sua preocupação com os rumos da revolução e pediu aos países latino-americanos mais solidariedade com o povo nicaraguense. Cortázar faleceu em 12 de fevereiro de $1984,{ }^{13}$ sem presenciar o desfecho do processo revolucionário nicaraguense, antes mesmo da eleição de Daniel Ortega para presidente do país, em novembro daquele ano. ${ }^{14}$

\section{Vargas Llosa: "Nicarágua na encruzilhada"}

O peruano Vargas Llosa foi à Nicarágua poucas vezes durante o governo sandinista. $\mathrm{O}$ que não o impediu de opinar sobre a revolução. Diferentemente dos textos militantes de Cortázar, Vargas Llosa imprimiu em todos os seus artigos sobre a Nicarágua um conteúdo histórico mais abrangente e informações precisas para situar o leitor naquele momento crucial para os nicaraguenses, quiçá para os latino-americanos. Todos os artigos sobre a Nicarágua estão reunidos em Contra viento y marea, volumes II e III. Em Nicarágua, año dos, publicado em 1981, Vargas Llosa declarou que a imprensa ocidental divulgava que o regime da Nicarágua já estava caminhando para um modelo bem próximo do "modelo totalitário tipo cubano ou soviético". Contudo, ele havia estado há pouco tempo no país e tinha podido comprovar que essa tese era exagerada e que não ajudava em nada os nicaraguenses. $\mathrm{O}$ que ele comprovou foi que Washington estava mais uma vez a ponto de cometer na Nicarágua o mesmo erro que cometera em Cuba, onde a conversão ao marxismo e o alinhamento com a órbita soviética foram provocados pela hostilidade e pelo bloqueio que a administração de Eisenhower ti- 
nha desencadeado contra o governo de Fidel Castro. Na Nicarágua, o governo de Reagan estava tomando um caminho semelhante, ao cancelar todos os créditos para o país, que inclusive já haviam sido aprovados pelo Congresso. Isso, a seu ver, servia apenas para aumentar o sentimento antiamericano e favorecer o radicalismo do governo sandinista. Para Vargas Llosa (1986: 308-309), os Estados Unidos, mais precisamente o governo Reagan, tinham a "obrigação moral” de agir com total prudência e ser generoso com os nicaraguenses, como tentou ser Jimmy Carter, para compensar os ataques ao seu território, as intervenções descaradas, as expedições de pilhagem e saque, a ocupação militar, o apoio incondicional ao "inspetor de latrinas Anastásio Somoza" e às suas linhagens.

Vargas Llosa, assim como Cortázar, lamentou que a solidariedade dos países democráticos com a Nicarágua fosse muito pequena; os exemplos eram poucos, como a Alemanha Ocidental, na Europa, e Venezuela e México, na América Latina. Durante sua permanência na Nicarágua, em julho de 1981, Vargas Llosa pôde perceber que no seio da Revolução Sandinista havia uma luta, quase sempre oculta, entre duas tendências: uma, sem deixar de ser radical, era pluralista e defendia um regime aberto, multipartidário, com liberdade de crítica; a outra, autoritária e dogmática, pretendia transformar a Nicarágua paulatinamente em um Estado marxista-leninista e fazer dela uma "nova Cuba". Naquele momento, a seu ver, essa luta ainda não tinha se definido. Por isso, era tarefa urgente que os países democráticos prestassem solidariedade à Nicarágua, para evitar que os nicaraguenses ouvissem "o canto da sereia" que vinha "do outro lado". Porque quando os nicaraguenses descobrissem que a ideologia e a ditadura socialistas não trariam o que eles esperavam seria tarde demais, e, mais uma vez, "se terá repetido a maldita história de sempre na América Central: de ditadura em ditadura, com pequenos intervalos de liberdade, para justificar a nostalgia". Para fugirem da ditadura socialista, os nicaraguenses deveriam seguir o exemplo de Pedro Joaquín Chamorro, ${ }^{15}$ que arriscou tudo, até a própria vida, para "lutar pela liberdade e pela verdade na Nicarágua". Após ler os escritos de Pedro Joaquín Chamorro, Vargas Llosa (1986: 311-312) ficou impressionado com a sua fé e entusiasmo pelo sistema democrático, "como ferramenta para edificar o progresso e assegurar a liberdade de um país". Para o escritor peruano, Pedro Joaquín Chamorro deveria ser tomado como símbolo para os "antagonismos em que se debatiam os nicaraguenses e sobre o destino do país, dois anos depois da vitória contra Somoza". A única alternativa possível para evitar que a Nicarágua se transformasse numa "nova Cuba", seria, na concepção de Vargas Llosa, se o regime mantivesse as instituições democráticas em pleno funcionamento. Depois que realizou uma extensa reportagem sobre o país, Vargas Llosa percebeu que isso não era tarefa fácil, principalmente após o aprofundamento da crise econômica e o fortalecimento da contrarrevolução. 
No início de 1985, Vargas Llosa esteve por um mês, de janeiro a fevereiro, no país centro-americano para fazer uma reportagem investigativa, que deu origem a Nicaragua en la encrucijada, uma espécie de dossiê dividido em 11 partes, ou 11 textos, publicados originalmente no The New York Times Magazine com o título de In Nicaragua. O momento na Nicarágua era histórico. Daniel Ortega havia tomado posse como presidente do país em 9 de janeiro e Vargas Llosa, como correspondente do jornal, havia chegado três dias antes para assistir à cerimônia de posse. Antes de chegar à Nicarágua passou pela Venezuela, onde ouviu de um amigo que o país de Sandino era quase uma Cuba e que ele tomasse cuidado, pois com a sua fama de direitista ele poderia se dar mal. Vargas Llosa confessou ter ficado assombrado com o teor da frase do venezuelano, pois defender a liberdade de expressão, as eleições livres e o pluralismo político era sinônimo de um intelectual de direita. No entanto, seu amigo estava errado: a Nicarágua não era uma segunda Cuba e ele foi muito bem recebido no país, tanto pelos sandinistas quanto pelos seus opositores. Vargas Llosa confessou que viveu um mês "intenso", "apaixonante" e "esquizofrênico" na Nicarágua. Conversou com centenas de pessoas, viajou por quase todo o país e viveu "experiências inolvidáveis". Em apenas um mês, Vargas Llosa entrevistou ministros, sindicalistas, empresários, agricultores, ex-presos políticos, comerciantes, jornalistas, feministas, evangélicos, poetas e padres. Visitou confrarias, igrejas, seminários e acompanhou procissões. Segundo ele, foi um exercício necessário, porque a religião era a melhor "porta de entrada" para compreender a "realidade política, social e cultural" da Nicarágua.

Em Manágua, as dificuldades da vida eram grandes e Vargas Llosa (1990: 251-254) compreendeu logo que, para os sandinistas, isso era consequência do subdesenvolvimento e, para os antissandinistas, culpa da Revolução. Para ele, o subdesenvolvimento e a Revolução tinham responsabilidades iguais. Percebeu que o correio era um desastre, a escassez de água era crônica e o transporte estatal um caos. Ao contrário de Cortázar, Vargas Llosa não viu nenhuma efervescência cultural promovida pela Revolução. Segundo ele, havia poucos cinemas, nos quais abundavam filmes antigos, estrangeiros e pornográficos. A televisão, também estatal, alternava propaganda do regime com séries norte-americanas "do mais duvidoso gosto". Apesar das edições locais terem se multiplicado, não se conseguia nem revistas, nem livros estrangeiros, salvo as edições cubanas e soviéticas em espanhol.

Em Manágua, havia pouca vida noturna, apenas uma taberna-livraria, onde se reuniam poetas, diplomatas, boêmios e os "onipresentes internacionalistas" (estrangeiros procedentes de países capitalistas, quase sempre jornalistas). Nos bares dos dois principais hotéis encontravam-se sobretudo estrangeiros. Os assessores cubanos, soviéticos, búlgaros e de outros países comunistas 
apareciam pouco em público. Contudo, relatou Vargas Llosa, quando queriam comer uma boa lagosta escolhiam o melhor restaurante de Manágua, La Marseillaise, e, ao invés de parecerem proletários, estavam sempre de "cabelos curtos e se vestiam como burgueses".

Parte do dossiê de Vargas Llosa (1990: 255-256) foi dedicado a responder uma pergunta cuja resposta muitos queriam saber: era a "Nicarágua um Estado marxista-leninista?" Estava “em vias de se tornar uma segunda Cuba?" Vargas Llosa fez questão de salientar que a situação de Cuba, após cinco anos de tomada do poder pelos revolucionários, era de completa dependência em relação à União Soviética. Assim, a sua sobrevivência econômica e militar dependia dela. Além disso, todas as ações da oposição foram suprimidas, o setor privado estava em vias de extinguir-se, a burocracia do Partido único estendia seus tentáculos por todo o país e a "regimentação ideológica era absoluta". Na Nicarágua, após cinco anos da queda de Somoza, a situação era diferente. Ainda que sob forte controle do Estado, o setor privado era ainda majoritário na agricultura, na pecuária, no comércio e na indústria. Mesmo com censura, existia um certo pluralismo informativo e havia partidos de oposição que expressavam de várias formas sua hostilidade ao regime sandinista. Na Nicarágua, a presença da União Soviética e dos países do Leste, com ajuda militar e técnica, não era suficiente para dizer que o país estivesse, assim como Cuba, na condição de "vassalo" da União Soviética; isso seria "uma distorção da realidade". Além do que, segundo ele, a União Soviética não estava em condições de assumir uma onerosa carga de uma segunda Cuba e o risco de uma nova confrontação direta com os Estados Unidos. Para Vargas Llosa, em grande medida, o que diferenciava o regime nicaraguense do cubano era a formação de uma economia mista e a constituição de um sistema político pluripartidário.

O projeto socialista da FSLN, na percepção de Vargas Llosa (1990: 256-257), sofreu reformulações que o deixaram mais moderado. Isso teria ocorrido devido a vários fatores: o impacto da evidência de que podiam contar pouco, financeiramente, com Moscou; a resistência interna contra a instalação de um regime marxista-leninista; as dificuldades econômicas geradas nos primeiros anos por uma política centralizadora e estatizante; e os prejuízos causados pelas sabotagens dos contrarrevolucionários. Tudo isso teria feito com que o projeto inicial dos sandinistas ficasse mais moderado e assumisse um modelo "vagamente neutralista, nacionalista e socializante". Algumas ações do governo comprovavam essa nova direção: a desvalorização da moeda, o fim de subsídios ao transporte e a certos produtos básicos, o anúncio da moratória na compra de armamentos, a retirada de cem assessores militares cubanos e as declarações dos sandinistas de que o regime era de economia mista e plural.

Vargas Llosa (1990: 260-262) reuniu-se por longas horas com a oposição ao regime que tentava de toda maneira provar a "natureza totalitária" do sandinismo, inclusive com acusações, segundo ele, inverificáveis. Quando ele insinu- 
ava que nos países totalitários que conhecia aquele tipo de reunião era inconcebível, eles reprovavam a sua ingenuidade. A seu ver, a oposição - representada por alguns partidos como o Conservador Democrata, o Liberal, o Social-Cristão e o Social-Democrata - defendia uma democracia liberal ortodoxa que a Nicarágua nunca teve e que não teria tampouco num futuro imediato. Além disso, em última instância, reduzia sua "estratégia ao catastrofismo" e esperava que os "contra", ajudados pelos Estados Unidos, resolvessem a situação derrubando o governo sandinista. Vargas Llosa não via a contrarrevolução como a melhor forma de oposição ao governo sandinista, pois gerava violência. Na sua concepção, se os "contra" quisessem derrotar de vez o sandinismo era preciso uma intervenção militar norte-americana massiva e sangrenta, o que não resultaria em democracia, mas numa ditadura. O único remédio para "salvar" a opção democrática na Nicarágua, um país corroído pelo terrorismo e pelas guerrilhas, era um entendimento pacífico com o regime.

A permanência de Vargas Llosa no país levou-o a concluir que quem assumia uma luta mais efetiva para evitar a consumação na Nicarágua de um projeto marxista-leninista eram os empresários, produtores agrícolas e a Igreja Católica. A instituição que agrupava os dois primeiros era o Consejo Superior de la Empresa Privada (COSEP), que, por sua vez, garantia a permanência de grandes negócios privados, como o Ingenio San Antonio - com 10.000 hectares de cana, cerca de 3.000 trabalhadores permanentes e 5.300 em época de safra, e com produção anual de 2.640.000 quilos de açúcar - e a Asociación Nacional de Arroceros (ANAR), filiada ao COSEP, com 9.000 hectares e $50 \%$ do arroz produzido no país. A ANAR comercializava toda a produção de arroz do setor privado, e, inclusive, a produção estatal com seus 10\% (Vargas Llosa, 1990: 263-268).

Vargas Llosa (1990: 273-274) declarou que a Nicarágua era o país mais católico que havia conhecido e que ali a religião era inseparável da política. Naquele período, início de 1985, a confrontação entre a Igreja e o governo sandinista, e a dissensão no seio da própria Igreja, era o embate mais decisivo no país. Segundo ele, quase todos os dirigentes da FSLN - inclusive "os mais impregnados de marxismo", como Tomás Borge e Carlos Fonseca Amador - haviam tido formação católica. A hierarquia da Igreja Católica enfrentou por várias vezes o regime somozista, e depois do triunfo revolucionário os sandinistas receberam o seu apoio por meio da Carta Pastoral (1979), que afirmava: "a Revolução é uma ocasião propícia para fazer realidade a opção da Igreja pelos pobres”. Porém, de acordo com Vargas Llosa, "a lua de mel durou pouco"; terminou quando o regime se radicalizou e passou a apoiar abertamente a Teologia da Libertação, ${ }^{16}$ que propunha a síntese do marxismo com o cristianismo e afirmava que o principal dever dos cristãos era o compromisso com a Revolução. Contudo, a FSLN, mes- 
mo antes de tomar o poder, já apoiava abertamente a Teologia da Libertação. A aproximação entre os dois movimentos ocorreu no final da década de 1960, após a Conferência Episcopal de Medellín (1968), que favoreceu o surgimento das Comunidades Eclesiais de Base (CEBs) na Nicarágua. Uma explicação plausível para o rompimento da hierarquia da Igreja com a FSLN pode estar na oposição de Roma à Teologia da Libertação. Principalmente depois que o papa João Paulo II, empossado em fins de 1978, intensificou as críticas ao movimento e impôs um maior controle sobre a Teologia da Libertação. Além disso, em 1984, o cardeal alemão Joseph Ratzinger, ${ }^{17}$ diretor da Congregação para a Doutrina da Fé (antigo Santo Ofício), publicou a Libertai Nuntius - Instrução sobre alguns aspectos da Teologia da Libertação, na qual criticava duramente a utilização da teoria marxista pelo movimento e estabelecia os aspectos do que deveria ser a teologia ideal, diferenciando-a da ala radical (Santos, 2006).

A Teologia da Libertação, segundo Vargas Llosa (1990: 274), identificava o pecado com as "estruturas sociais injustas do capitalismo" e, em sua versão mais extremista, proclamava que "o marxismo era a única solução para o mundo". Dessa forma, a Nicarágua havia se convertido "no paraíso de católicos socialistas, de teólogos radicais, de profetas apocalípticos e de curas marxista-leninistas provenientes do mundo inteiro". Para ele, o governo sandinista, que tinha em seu governo quatro sacerdotes revolucionários, ${ }^{18}$ havia promovido a "Igreja Popular, acreditando que ela dotaria a Revolução de um nimbo cristão, sem limitar seu radicalismo".

Para Vargas Llosa (1990: 274), quando se falava de disputa entre a "Igreja Popular" e a hierarquia católica, quase sempre se pensava que a primeira representava as massas humildes de fiéis com seus pastores, e a segunda "uma falange de bispos teratológicos e um punhado de ultramontanos e entreguistas cegos e surdos aos ventos da História". A seu ver, na realidade, a "Igreja Popular" era pouco popular porque os sacerdotes e laicos que a conformavam possuíam rigor, refinamento intelectual e trabalhos sociopolíticos que estavam "fora do alcance do católico comum" e "sobretudo dos pobres". Além disso, os esforços para denunciar o papel histórico da Igreja a serviço dos poderes dominantes e para revestir a luta de classes e o anti-imperialismo de simbologia evangélica tinham eco apenas nos setores intelectuais e militantes da classe média, já convencidos de antemão. Ademais, "o grosso dos católicos nicaraguenses, como os do resto da América Latina, não professavam essa religião reflexiva, intelectualizada e crítica" proposta pela "Igreja Popular", senão a "fé intuitiva, disciplinada, ritual" defendida pela hierarquia católica.

Contudo, na Nicarágua, os teólogos da libertação faziam questão de uma aproximação religiosa e política com "os populares". Durante as festividades religiosas, os retratos dos guerrilheiros sandinistas mortos eram colocados lado a lado 
com os dos santos católicos. Na festa da Puríssima - Imaculada Conceição-o altar da Virgem era adornado com consignas anti-imperialistas. Além disso, usavam a Rádio Católica para uma maior aproximação com os fiéis e para mostrar que a Revolução Sandinista era a primeira revolução socialista da história que não possuía um caráter anticristão e anticlerical (Van Eeuwen, 1994: 192-193).

Em vários depoimentos de teólogos de esquerda ouvidos por Vargas Llosa (1990: 279-281), eles afirmavam que não eram "cegos apologistas" do regime sandinista e que, inclusive, haviam protestado contra abusos aos direitos humanos e também contra a perseguição de sacerdotes não sandinistas. Nos depoimentos dos bispos, os temas abordados eram, segundo ele, mais "conflitivos", como as críticas ao recrutamento obrigatório para o Serviço Militar Patriótico. ${ }^{19}$ Nos seus púlpitos, os sacerdotes e bispos atacavam o marxismo com frequência e denunciavam "qualquer indício de totalitarismo, de ateísmo ou de perseguição religiosa". Todavia, para o peruano, às vezes, os bispos se mostravam pouco compreensivos com as dificuldades em que se debatia a Revolução e menosprezavam os esforços que o governo fazia a favor dos pobres. De qualquer forma, Vargas Llosa considerava a "campanha frontal da Igreja" - mais que a crise econômica e a pressão externa - como um importante "freio à tentação totalitária do regime”.

O que fortaleceu ainda mais a convicção de Vargas Llosa de que na Nicarágua a religião era inseparável da política foi sua investigação sobre a aparição da Virgem de Cuapa. O escritor peruano entrevistou Bernardo, um sacristão que nos 1980 teria visto a imagem da Virgem Maria na capela da aldeia de Cuapa, no departamento de Chontales, no centro do país. Na primeira das oito aparições, a Virgem pediu aos nicaraguenses que rezassem o rosário reunidos em família e os exortou a amar uns aos outros, a cumprir seus deveres e a trabalhar pela paz. Vargas Llosa percebeu, pelos relatos de Bernardo, que os dizeres da Virgem possuíam fortes "reverberações políticas": a "Nicarágua tem sofrido muito desde o terremoto ${ }^{20}$ e seguirá sofrendo se vocês não mudarem. Se não o fizerem, abreviarão a vinda da terceira guerra mundial". Na segunda visita da Virgem, Bernardo perguntou o que ela pensava sobre os sandinistas, ao que ela respondeu: "são ateus, comunistas, e por isso venho ajudar os nicaraguenses. $\mathrm{O}$ que eles prometeram não têm cumprido. Se vocês não observarem meus pedidos, o comunismo se estenderá por toda a América" (apud Vargas Llosa, 1990: 283-284).

O sacristão disse a Vargas Llosa que ainda não podia revelar tudo o que a Virgem havia dito, pois o bispo Pablo Antonio Vega ainda não o tinha permitido relatar todo o milagre. Porém, confessou a Vargas Llosa que recebera a visita de três funcionários do governo que lhe ofereceram "uma fazenda de boas terras, cheia de gado" se ele dissesse que "a Virgem era sandinista". Bernardo recusou a proposta justificando que não "podia faltar com a verdade". Os funcionários te- 
riam insistindo, dizendo que bastava então que ele dissesse que a Virgem não era antissandinista. Mais uma vez o sacristão recusou a oferta dizendo que não podia traí-la. A Virgem de Cuapa tornou-se então um objeto de culto na Nicarágua. Segundo informações de Vargas Llosa (1990: 285), dezenas de milhares de fiéis visitavam com frequência o lugar onde ela supostamente aparecera, e, quando podia, o jornal de oposição, La Prensa, noticiava as romarias. Todos os esforços da "Igreja Popular" para "conjurar o marianismo burguês" e os "contrarrevolucionários" foram em vão. Vargas Llosa concluiu que essa "não era uma história medieval", ocorria na Nicarágua, e sua importância política era considerável: "Crer ou não crer na Virgem de Cuapa" situava "ideologicamente as pessoas" e as "alinhava no confronto político do país".

Outra preocupação de Vargas Llosa (1990: 286-287) foi compreender a censura que se estabelecia no seio do regime sandinista, principalmente aquela imposta ao jornal La Prensa, "porta-voz e catalisador de todas as formas de oposição ao regime sandinista". Todo o conteúdo do jornal deveria ser submetido ao Ministério do Interior antes da edição, onde era averiguado e depois devolvido com as indicações de parágrafos, fotografias, artigos e títulos a serem modificados ou suprimidos. Inclusive chegaram a suprimir quase a quarta parte do jornal $\mathrm{La}$ Prensa. Quando entrevistou Tomás Borge, Vargas Llosa lhe perguntou se o regime não tinha a noção de que "a censura era um dos motivos de maior desprestígio para sua imagem no mundo". O comandante sandinista lhe respondeu que o país vivia "uma guerra de agressão" e que enquanto não cessassem "os ataques e sabotagens da CIA e dos bandos mercenários contra o país", a censura não terminaria. O presidente Daniel Ortega, ao ser questionado sobre o mesmo tema, explicou-lhe que na Nicarágua não aconteceria o mesmo que aconteceu no Chile de Allende, onde "a desestabilização do regime ocorreu por culpa dos meios de comunicação manipulados pela CIA". Vargas Llosa explicou que vários sandinistas, como Jaime Wheelock, viveram no Chile na época de Allende e que por isso o que havia ocorrido com a Unidade Popular os deixava obcecados.

A censura a La prensa, como observou Vargas Llosa (1990: 287), não era de todo eficaz, pois os textos suprimidos circulavam de mão em mão em fotocópias e eram comentados nas ruas ou lidos por telefone. Além disso, existiam rádios antissandinistas que desde Honduras transmitiam programas que poderiam ser escutados em vários lugares. A consequência mais grave dessa censura, ainda sem muita eficácia, era, para Vargas Llosa, o empobrecimento e a contração do debate político nos meios de comunicação. Na verdade, não havia debate, somente "ataques e incompreensões recíprocas". O nível do conteúdo dos diários oficiais, como Barricada, era baixíssimo e predominava o sensacionalismo, e La Prensa caía no vazio ao chamar Daniel Ortega de "titular do Executivo", assim como fazia Pedro Joaquín Chamorro com Somoza. 
Em 1985, durante sua estadia em Manágua, Vargas Llosa realizou quatro entrevistas com Tomás Borge. Antes de fazer qualquer comentário sobre a entrevista no dossiê Nicaragua en la encrucijada, o escritor peruano traçou o perfil daquele que, a seu ver, era o mais eloquente entre os líderes sandinistas e um dos principais símbolos da revolução nicaraguense: o comandante Tomás Borge, ministro do Interior, um dos nove membros da Direção Nacional da Frente Sandinista e também "uma relíquia histórica". Foi um dos fundadores da FSLN em 1961 e o único sobrevivente do início da luta revolucionária. Começou a conspirar contra Somoza aos 14 anos e, dos 54 que tinha, passou seis na prisão, cinco nas montanhas como guerrilheiro e 19 na clandestinidade. Entre todos, era o "mais eloquente, o mais propenso a confundir seus desejos com a realidade e o mais simpático" (Vargas Llosa, 1990: 288).

Na primeira das quatro entrevistas que Vargas Llosa fez com Tomás Borge, o líder sandinista lhe disse que era uma lástima alguém como ele escrever tão boas novelas, mas ter péssimas ideias políticas. Vargas Llosa (1990: 289-291) retrucou e perguntou-lhe se o que diziam sobre ele era verdade, isto é, se ele era o mais "duro" da revolução, o "homem de Moscou e de Cuba" e o marxista-leninista mais convicto entre os dirigentes sandinistas. O que mais deixou Tomás Borge raivoso, segundo Vargas Llosa, foi a acusação de ser "duro": "Dizem isso de mim? Filhos da puta! Sou o mais brando de todos. Deixa-me dizer uma coisa: se eu tivesse sido o candidato nas eleições de novembro, os burgueses deste país teriam votado em mim.” Para devolver a provocação, Tomás Borge perguntou a Vargas Llosa porque ele não era um revolucionário como García Márquez e Cortázar. O escritor peruano lhe explicou, "sem muito sucesso", que sem liberdade todas as reformas sociais, tarde ou cedo, se frustram.

Tomás Borge fez uma espécie de reunião em homenagem a Vargas Llosa com a presença de poetas e romancistas, entre eles Ernesto Cardenal, que, apesar de ser um "excelente poeta", Vargas Llosa (1990: 292-293) considerava um "demagogo", capaz de "dizer bobagens" como: "a sociedade comunista é o verdadeiro reino do céu". Nesta reunião também estava presente o cubano Fernández Retamar, que Vargas Llosa não via desde fins dos anos 1960, desde que passara a criticar a Revolução Cubana. Como escritores civilizados, eles conversaram, recordaram amigos e trocaram pequenas alfinetadas. Vargas Llosa "descobriu" durante a conversa que quase todos os escritores cubanos com quem teve relações quando frequentava a ilha tinham ido para o exílio. Fernández Retamar fez questão de lhe dizer que muitos dos escritores jovens liam seus romances, e isso era prova de que em Cuba não havia sectarismo e que quando Vargas Llosa quisesse voltar a Cuba seria muito bem recebido. Ironicamente, deu sua "palavra de que não o mandariam para o gulag". Vargas Llosa, por sua vez, agradeceu o convite e assegurou que, em caso de necessidade, Fernández Retamar poderia contar com 
sua casa e sua hospitalidade no Peru ou na Europa. Apesar de civilizado, o encontro foi marcado por posições irônicas de ambos os lados.

Em uma das entrevistas que fez com Tomás Borge, Vargas Llosa quis saber quantos prisioneiros políticos existiam na Nicarágua. Segundo o líder sandinista, havia cerca de seis mil presos, dos quais dois mil eram guardas somozistas e uns duzentos eram "contra". Segundo a oposição, estas cifras eram maiores, havendo um total de dez mil presos no país. A maioria dos presos políticos estava na prisão da Zona Franca, onde, segundo a Comissão Permanente pelos Direitos Humanos, viviam cerca de mil presos em condições subumanas. ${ }^{21}$ Vargas Llosa pediu autorização a Tomás Borge para visitar a Zona Franca e este lhe prometeu a visita, mas, ao invés de leva-lo lá, o levou para visitar uma das sete "granjas abertas", que ficava próxima a Manágua, onde havia 59 presos, todos ex-guardas de Somoza condenados a diversas penas. Ali, plantavam milho, feijão e outros produtos alimentícios. Não havia vigilância e o lugar era regido por um conselho de presos presidido por um ex-sargento condenado a 20 anos de prisão. Recebiam visitas todos os domingos e a cada seis meses os presos podiam passar uma semana com sua família (Vargas Llosa, 1990: 294).

A popularidade do governo sandinista, para Vargas Llosa (1990: 297-298), era difícil de ser medida, pois as estruturas de enquadramento da população dificultavam o cálculo. Os Comitês de Defesa Sandinista (CDSs), a exemplo dos CDRs cubanos, inscreviam a população nas ruas e nos bairros quem não pertencesse aos comitês "tornava-se um pária" -, porque era através deles que a população recebia os cupons para adquirir os produtos básicos racionados e subsidiados. Além disso, os comitês emitiam certificados de boa conduta para obter passaportes, para ser admitido em empregos públicos e requerer bolsas de estudo. Os CDSs também participavam da campanha de alfabetização e de vacinação em massa, e, juntamente com a polícia, contribuíam para diminuir a delinquência e o uso de drogas. Apesar de os comitês "prestarem uma valiosa contribuição às grandes campanhas cívicas", para Vargas Llosa eles tinham uma função principal: "ser os olhos e os ouvidos do regime"; faziam parte de um "todo-poderoso sistema de espionagem e manipulação". 22

Para Vargas Llosa (1990: 299), a guerra, as sabotagens dos “contras", as medidas autoritárias do governo, a crise econômica e a tensão política teriam esfriado o apoio ao governo sandinista, que, a princípio, era quase unânime. Porém, a seu ver, não havia dúvidas de que nos setores populares o respaldo aos sandinistas ainda era grande, pois recebiam da Revolução benefícios concretos no campo da saúde, educação e distribuição de terras. Ainda que, em muitos casos, "a política estatizadora e a crise econômica tinham frustrado os alcances dessas reformas". Os nicaraguenses tinham acesso aos hospitais, mas os hospitais não tinham infraestrutura para recebê-los. Além disso, os preços baixos dos produ- 
tos básicos da alimentação mediante subsídios fizeram com que a produção caísse, pois os camponeses achavam melhor comprá-los nos armazéns estatais do que cultivá-los. Apesar disso tudo, Vargas Llosa acreditava que o "impulso igualitário" e a vontade de reparar anos de abusos e sofrimento exerciam "um poder de persuasão grande no povo". Todavia, não estava sendo possível a conciliação do impulso igualitário com o impulso libertário. O que, segundo Vargas Llosa, não era característica apenas da Revolução Sandinista, mas de todas as revoluções socialistas que sacrificavam a liberdade em nome da justiça social. O ideal era que liberdade e igualdade não fossem vistas como antagônicas, mas como parte de um mesmo processo.

Para Vargas Llosa (1990: 302-304), cinco anos depois do triunfo revolucionário, os sandinsitas estavam descobrindo - uns menos, outros mais - que transformar uma sociedade "era mais difícil do que montar emboscadas, atacar quartéis ou assaltar bancos". Porque "as supostas leis da história reduzem-se a pedaços diante dos condicionamentos brutais do subdesenvolvimento e da diversidade dos comportamentos humanos". Vargas Llosa concluiu o seu dossiê afirmando que os sandinistas não iriam conceber aquilo que a oposição queria, ou seja, "a democracia plena", na qual compartilhassem o poder e pusessem o destino da Revolução "nas mãos de contingências" como eleições livres, liberdade de imprensa, divisão de poderes e instituições representativas. Por um simples motivo: "não foi por esse tipo de democracia que subiram as montanhas" e nem era "essa a legalidade" que defendiam. Acreditavam que a "legitimidade era dada pelas armas" que conquistaram o poder, e, uma vez conquistado o poder, não era necessário compartilhá-lo.

Ao contrário do que afirmou Vargas Llosa em 1985, os sandinistas puseram o "destino da Revolução nas mãos" de certas "contingências": convocaram eleições para presidente em 1990 e perderam o pleito para Violeta Chamorro. Apesar de se colocar como herdeira direta dos princípios democráticos que defendia Joaquín Chamorro, Violeta Chamorro foi eleita com o apoio dos Estados Unidos e de setores da direita nicaraguense, em uma ampla aliança de centro-direita chamada de União Nacional Opositora (UNO). Sobre o fim do governo sandinista? Nenhuma linha foi escrita por Vargas Llosa, que estava demasiadamente envolto na campanha eleitoral para presidente do Peru, da qual também saiu derrotado.

Durante sua permanência na Nicarágua, Vargas Llosa foi capaz de compreender as dificuldades pelas quais passava o governo sandinista, e, por outro lado, o que movia os movimentos de oposição. Porém, não foi capaz de compreender que a experiência sandinista, pela sua própria essência, não se encaixava totalmente na sua concepção liberal de democracia. Para Cortázar, decidido a mostrar para o mundo as conquistas sociais e culturais do processo, o cenário sob 
o qual estava transcorrendo a experiência sandinista era prova inequívoca de que a Revolução seguia seu rumo certo. Cortázar optou, por motivos óbvios, pela militância política e redigiu textos com a preocupação de defender a Revolução e mostrar que a experiência sandinista sempre foi marcada pelos conflitos entre $o$ bem e o mal, entre Davi e Golias. Apesar das posturas diversas, os dois escritores acreditavam que a experiência sandinista seria a síntese de um longo percurso que teria se iniciado com a Revolução Cubana.

Notas

1. A Nicarágua conquistou formalmente sua independência nos inícios do século XIX, mas ao longo desse século o país foi submetido a sucessivas agressões militares dos Estados Unidos. No início do século XX, os EUA fortaleceram suas ações no país e suas tropas permaneceram estacionadas no território nicaraguense por 21 anos. Em 1933, as tropas foram retiradas e os EUA passaram a exercer uma dominação menos direta. Era o momento em que os EUA deixavam a política do Big Stick e adotavam a chamada Política de Boa Vizinhança. Em 1936, Anastasio Somoza, mediante um golpe de Estado, tomou o poder na Nicarágua. Com o apoio dos Estados Unidos, a família Somoza permaneceu no poder por 43 anos, até a vitória da FSLN em 1979. Nesse período, o país foi governado por Anastasio Somoza García (1936-1956), Luis Somoza Debayle (19561967) e Anastasio Somoza Debayle (19671979). Cf. Barahona Portocarrero (1990).

2. Na luta contra a ocupação militar norte-americana, Sandino liderou o Exército Defensor da Soberania da Nicarágua. Em $1934-$ depois da retirada dos marines pelos EUA e da deposição das armas pelas forças de Sandino no ano anterior -, o líder rebelde foi assassinado e as bases sociais do movimento foram reprimidas a mando de Anastasio Somoza, então chefe da Guarda Nacional, um "exército" criado pelos Estados Unidos com auxílio do governo nicaraguense, que se consti- tuiu em um instrumento de poder da família Somoza ao longo de sua permanência no governo. Cf. Selser (1979) e Barahona Portocarrero (1990).

3. Em julho de 1979, tomou posse a Junta de Governo de Reconstrução Nacional, formada por cinco membros, representantes de distintas forças políticas e sociais: Daniel Ortega, da FSLN; Moisés Hassán, do Movimento Povo Unido e Frente Patriótica Nacional; Sérgio Ramírez, do Grupo dos Doze; Violeta Chamorro, líder da União Democrática de Libertação; e Alfonso Robelo, da Frente Ampla de Oposição.

4. Depois da vitória da FSLN, Cortázar viajou seis vezes para a Nicarágua: setembro e novembro de 1979; março, julho-agosto de 1982; janeiro e julho de 1983.

5. O compromisso de Cortázar com a causa socialista se deu a partir da Revolução Cubana. Foi também a partir dela que o argentino manifestou interesse, desde Paris, pela realidade social e política da América Latina. Porém, em fins da década de 1960, a Revolução Cubana deixou de contar com o "apoio entusiasta" de grande parte da intelectualidade de esquerda, incluindo Cortázar, por várias razões: o forte alinhamento de Cuba com a URSS, moldando o modelo cubano ao chamado socialismo realmente existente; as acusações sobre os 
rumos equivocados da revolução - perseguições, torturas, prisões e censura - e o polêmico "caso Padilla". O poeta cubano Heberto Padilla recebeu o prêmio Casa de las Américas em 1967 e, em seguida, foi destituído do prêmio e expulso da União dos Escritores de Cuba por causa de suas opiniões sobre a Revolução. Em 1971, Padilla foi preso e fez - ou, como muitos afirmam, foi coagido a fazer - uma autocrítica, negando tudo que havia dito anteriormente. Isso desencadeou uma onda de protestos por parte de antigos aliados de Cuba, como, entre outros, Jean-Paul Sartre e Mario Vargas Llosa.

6. Ernesto Cardenal fundou, em 1966, a comunidade de Solentiname, localizada em uma ilha no lago de Nicarágua. Essa comunidade foi uma grande referência artístico-revolucionária para os sandinistas. Em Solentiname, os camponeses produziam quadros destacando um Cristo camponês e revolucionário. Em 1977, a Guarda Nacional atacou e destruiu toda a comunidade. Após o triunfo revolucionário dos sandinistas, Cardenal foi nomeado ministro da Cultura do novo governo. Cf. Cardenal (2004 e 2006).

7. A partir de 1981, quando Ronald Reagan assumiu a presidência do país, os Estados Unidos imprimiram um tom mais agressivo à política externa norte-americana e travaram um embate incisivo contra os sandinistas, financiando grupos contrarrevolucionários, também chamados de "contras". A oposição também englobava a hierarquia da Igreja, os partidos conservadores tradicionais, o Consejo Superior de la Empresa Privada (COSEP) e o jornal La Prensa. Cf. Rodrigues (1996) e Lozano (1987).

8. De acordo com Emir Sader (1992), os sandinistas tiveram que dispensar recursos crescentes para a defesa. Em 1983, $40 \%$ do orçamento do governo era destinado à "guerra", o que contribuiu para desequilibrar a economia do país.

9. Cf. Zimmermann (2006) e Gott (2006).
10. Julio Silva era pintor, escultor e artista gráfico argentino. Cortázar enviou a carta para Julio Silva de Paris, ou seja, antes de sua ida para a zona de fronteira, quando não sabia ainda que Claribel Alegría iria acompanhá-lo na "Vigília em Bismuna".

11. Sobre o "intelectual orgânico", ver Gramsci (1995).

12. Casa de las Américas, n. 15-16, nov-fev. de 1963.

13. Cortázar, bastante abatido pela leucemia, morreu de ataque cardíaco em Paris. Seu corpo está enterrado no cemitério de Montparnasse, na França, ao lado de sua última esposa, Carol Dunlop.

14. Em novembro de 2006, Daniel Ortega foi eleito novamente presidente da $\mathrm{Ni}$ carágua pela FSLN - que se transformou em partido político - e deverá permanecer no poder até 2011.

15. O jornalista Pedro Joaquín Chamorro foi diretor do diário La Prensa e líder de um movimento de oposição ao governo de Anastacio Somoza Debayle, chamado Unión Democrática de Liberación (UDEL). Em 1978, foi morto a tiros a mando do governo. Cf. Salazar Valiente (1990: 273).

16. Sobre a Teologia da Libertação, ver Silva Gotay (1986) e Rojas (1986).

17. O Cardeal Joseph Ratzinger foi empossado como Papa Bento XVI em 2005.

18. Participaram do governo o ministro do Exterior, Miguel d'Escoto; da Cultura, Ernesto Cardenal; da Instrução, Fernando Cardenal; do Bem-Estar Social, Edgard Parrales. Em fins de 1984, o Vaticano e o acerbispo de Manágua, Miguel Obando Y Bravo, exigiram que os quatro padres renunciassem a seus cargos no governo sob pena de serem suspensos a dinivis. Nenhum deles renunciou ao cargo. Edgard Parrales terminou renunciando ao sacerdócio e os outros três "preferiram ser marginalizados, não aceitando uma 
imposição que, a juízo deles, não nasce de preocupações teológicas, mas antes da vontade de 'deslegitimar a Revolução sandinista', e, como comprovação disso, recordaram que existiam no mundo 140 padres ocupando cargos públicos ou de partido, sem que por isso jamais tenham sido submetidos a esse tipo de imposição. Numa 'Carta aos Amigos', divulgada em Manágua a 11 de dezembro de 1984, o padre Fernando Cardenal escreveu que 'a política vaticana para a Nicarágua coincide com a do presidente Reagan'” Cf. Invernizzi (1985: 79).

19. O governo sandinista, para intensificar suas defesas militares, instituiu em 1983 o Serviço Militar Patriótico. A lei exigia que todos os rapazes entre 17 e 25 anos se apresentassem para o serviço militar e autorizava a participação de mulheres entre 18 e 40 anos. A população fazia de tudo para evitar que seus filhos fossem enviados para o Exército Popular. Os pais da classe média enviavam para Miami os seus filhos, e os camponeses escondiam seus filhos em idade de prestar o serviço militar. Por conta dessa evasão, os sandinsitas convocavam jovens sem a idade legal para as fileiras do Exército. Para muitos especialistas, a lei do serviço militar obrigatório foi uma das medidas mais controversas do governo sandinista e foi um fator de peso para a derrota eleitoral da FSLN no pleito de 1990. A lei provocou violenta reação da Igreja Católica,

\section{Referências bibliográficas}

\section{Fontes documentais}

Julio Cortázar

Cartas: 1969-1983.

Buenos Aires: Alfaguara, 2000.

Nicarágua tão violentamente doce.

São Paulo: Brasiliense, 1987. que declarou numa Carta Pastoral que o jovem que se alistava terminava por "servir militarmente não à pátria, mas a um partido, 0 sandinista, e seria enviado para combater uma guerra fratricida contra um inimigo (os "contra") que, embora, pago, treinado e armado nos Estados Unidos, continuava a ser nicaraguense." Cf. Zimmermann (2006: 133-134) e Invernizzi (1994: 89).

20. Em 1972, a Nicarágua sofreu um intenso terremoto que trouxe inúmeros problemas para o país.

21. A Comissão Permanente pelos Direitos Humanos, criada no país em 1977, denunciava as detenções e as perseguições políticas. Em 1987, segundo a oposição, o número de prisioneiros políticos variava entre 9.000 a 10.000; segundo a Corte Suprema, de 8.000 a 8.500 ; segundo as autoridades sandinistas, o número de prisioneiros não passava de 8.000 , divididos em 4.000 presos comuns, 2.000 contrarrevolucionários, 2.000 ex-membros da guarda somozista. Cf. Van Eeuwen (1994: 187-188).

22. Os CDSs eram organizados por bairros para facilitar a vigilância e garantir a participação em campanhas cívicas e de distribuição de alimentos. Em 1985, havia em Manágua 3.400 CDSs com aproximadamente 77.000 membros, quase um para cada 10 habitantes. Cf. Van Eeuwen (1994: 186).

Para Solentiname.

Vuelta, México, fevereiro de 1978, p. 47-51.

Mario Vargas Llosa

Contra viento y marea II (1972-1983).

Barcelona: Seix Barral, 1986.

Contra viento y marea III (1964-1988).

Barcelona: Seix Barral, 1990. 


\section{Fontes bibliográficas}

BARAHONA PORTOCARRERO, Amaru. Breve estudo sobre a história contemporânea da Nicarágua. In: GONZÁLEZ CASANOVA, Pablo (org.). América Latina: história de meio século, 3 vols. Brasília: EdUnB, 1990.

CARDENAL, Ernesto. La revolución perdida: memoria 3. Madri: Trotta, 2004.

dri: Trotta, 2006.

DIOGO, Rita de Cássia Miranda. Lite- ratura e autoritarismo na América Latina. Línguas e Letras, Unioeste, Paraná, vol. 6, n. 10, 2005, p. 61-72.

GRAMSCI, Antonio. Os intelectuais e a organização da cultura. Rio de Janeiro: Civilização Brasileira, 1995.

LÖWY, Michael. Marxismo e Teologia da Libertação. São Paulo: Cortez, 1991.

LOZANO, Lucrecia \& BERMÚDEZ, Lilia. EE. UU. Contra Nicarágua: la guerra de baja intensidad en centroamérica. Madri: Revolución, 1987.

RODRIGUES, Lygia. O sandinismo e a revolução nacional democrática. In: DAYRELL, Eliane G. \& IOKOI, Zilda M. Gricoli (orgs.). América Latina contemporânea: desafios e perspectivas. Rio de Janeiro: Ex- pressão e Cultura; São Paulo: Edusp, 1996. (Col. América: raízes e trajetórias, 4)

ROJAS, Gonzalo. El Vaticano II en América Latina veinte años de posconcilio. Cuadernos Hispanoamericanos, Madri, n. 431, maio de 1986.

SADER, Emir. Cuba, Chile, Nicarágua: socialismo na América Latina. São Paulo: Atual, 1992.

SALAZAR VALIENTE, Mario. Nicarágua. Os últimos anos. In: GONZÁLEZ CASANOVA, Pablo (org.). América Latina: história de meio século. S. ed., 1990.

SANTOS, Irinéia M. Franco. 40 anos de Teologia da Libertação. Anais do XVIII Encontro Regional de História-Ohistoriadore seu tempo. Anpuh/SP-Unesp/ Assis, 24 a 28 de julho de 2006. Cd-rom.

SELSER, Gregório. Sandino: general de homens liores. São Paulo: Global, 1979.

SILVA GOTAY, Samuel. El pensamiento religioso. In: ZEA, Leopoldo (coord.). América Latina en sus ideas. México: Siglo Veintiuno, 1986.

VAN EEUWEN, Daniel. Nicarágua. In: ROUQUIÉ, Alain. (coord.) Las fuerzas políticas en América Central. México: Fondo de Cultura Económica, 1994.

ZIMMERMANN, Matilde. $A$ revolução $n i-$ caraguense. São Paulo: Unesp, 2006.

\section{Resumo}

No final dos anos 1970 e início dos 80, Julio Cortázar e Mario Vargas Llosa compararam a Nicarágua sandinista com a Cuba de Fidel Castro, colocando em dia o debate sobre a revolução e o socialismo na América Latina. $\mathrm{O}$ presente trabalho analisa os artigos de Cortázar e Vargas Llosa para mostrar como eles compreenderam e traduziram a experiência sandinista. Em fins dos anos 1970, muitos intelectuais passaram a defender a Revolução Sandinista, como a possível revolução ideal ou uma nova chance para a experiência 
socialista na América Latina, como foi o caso de Cortázar. Vargas Llosa, desencantado com as esquerdas, apontava os "erros" do regime que poderiam levar a experiência sandinista a transformar o país centro-americano em uma "nova Cuba".

Palavras-chave: Cortázar, Vargas Llosa, Revolução Sandinista, Revolução Cubana, América Latina

\begin{abstract}
At the end of the 1970's and the beginning of the 1980's, Julio Cortázar and Mario Vargas Llosa compared the sandinista Nicaragua to the Fidel Castro's Cuba, renewing the debate about revolution and socialism in Latin America. This paper analyses Cortázar and Vargas Llosa's articles to demonstrate how they have understood and translated the sandinista experience. At the end of the 1970's, many intellectuals began to defend the sandinista Revolution as the possible ideal revolution or as a new chance to the socialist experience in the Latin America, and that was the case of Cortázar. Vargas Llosa, disappointed with the left, pointed out the regime's "mistakes" that might take the sandinista experience to turn Nicaragua into a "new Cuba".
\end{abstract}

Key words: Cortázar, Vargas Llosa, Sandinista Revolution, Cuban

Revolution, Latin America

\author{
Résumé \\ À la fin des années 1970 et au début des années 1980, Julio Cortázar et Mario \\ Vargas Llosa ont comparé le Nicaragua sandiniste à la Cuba de Fidel Castro, \\ renouvelant la discussion sur la révolution et le socialisme en l'Amérique \\ Latine. Ce travail analyse les articles de Cortázar et Vargas Llosa pour \\ montrer comment ils ont compris et ont traduit l'expérience sandiniste. À la \\ fin des années 1970, beaucoup d'intellectuels ont passé à defendre la \\ Révolution Sandiniste comme la possible révolution idéale ou comme une \\ nouvelle chance pour l'expérience socialiste en Amérique latine, comme l'a \\ fait Cortázar. Vargas Llosa, déçu par la gauche, a indiqué les "erreus" du \\ régime qui pourraient emmener l'expérience sandiniste a transformer le \\ Nicaragua en une "nouvelle Cuba". \\ Mots-clés: Cortázar, Vargas Llosa, Révolution Sandiniste, Révolution \\ Cubaine, Amérique Latine
}

